\title{
Analytical Dimensions for Identifying Social Innovations: Evidence from Collective Enterprises
}

\author{
Ângela Maria Maurer ${ }^{\dagger}$ \\ Universidade Federal do Rio Grande do Sul - UFRGS \\ Tânia Nunes da Silva ${ }^{\Omega}$ \\ Universidade Federal do Rio Grande do Sul - UFRGS
}

\begin{abstract}
Social innovations are seen as alternatives to address social and environmental problems facing humanity. However, the term covers a broad range of definitions which can include a variety of initiatives. Based on analytical dimensions of social innovations, this study sought to assess to what extent the emergence of collective enterprises in the Brazilian handicraft sector is consistent with the dimensions postulated in the literature. Drawing on a multiple case study, the results showed that the analytical dimensions of social innovation identified the main elements involved in developing solutions with a significant number of actors, which indicates they are appropriate for understanding the formation of collective enterprises in the handicraft sector. This study has enabled, therefore, an understanding of how social solutions are built collectively and can be used to generate other social innovations or improvements to existing ones.
\end{abstract}

Keywords: Social innovations. Social innovations dimensions of analysis. Solidarity economy. Brazilian collective enterprises.

Received on April 12, 2013; accepted on July 15, 2013 ; disclosed on November 27, 2014.

*Autor para correspondência:

${ }^{\dagger}$. Master by Programa de Pós Graduação da Universidade Federal do Rio Grande do Sul Institution: Doctorate student in Universidade Federal do Rio Grande do Sul

Address: Rua Washington Luis, Porto Alegre RS - Brazil - E-mail:

maurer.angelamaria@gmail.com Telephone: (51) $3308-3536$

\footnotetext{
${ }^{\Omega}$ Doctor by Faculdade/Instituto/Centro Sociologia da Universidade USP/SP

Institution: Professor of Universidade Universidade Federal do Rio Grande do Sul

Address: Rua Washington Luis, Porto Alegre - RS - Brazil

E-mail: tania.silva@ufrgs.br

Telephone: (51) 3308.3536
}

Nota do Editor: Esse artigo foi aceito por Emerson Mainardes 


\section{INTRODUCTION}

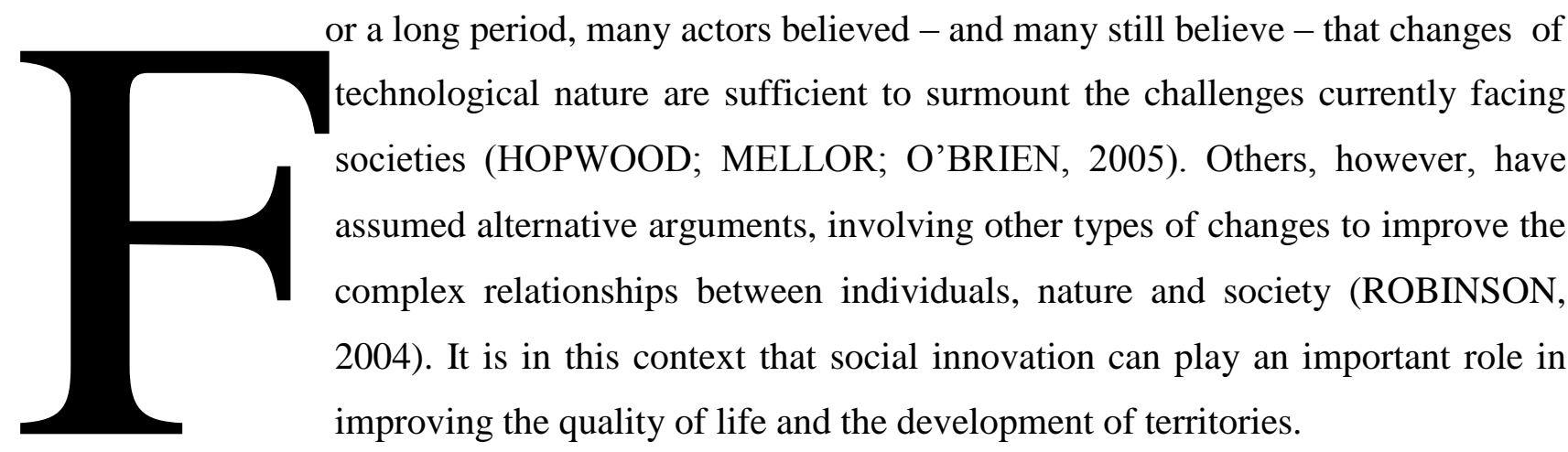

One of the most widespread definitions of social innovation refers to innovative solutions to human needs (MULGAN, 2006). Other definitions involve a larger number of elements, such as that of the Centre de Recherche sur les Innovations Sociales (CRISES), which conceives social innovation as "an intervention initiated by social actors to respond to an aspiration, to meet specific needs, to offer a solution or to take advantage of an opportunity for action" (CRISES 2012, p.4; BOUCHARD, 2012, p.50). Thus, it can bring about changes in social relations, to transform a framework of action or propose new cultural orientations. The CRISES is the one of the main research centers for social innovation in Canada (ANDREW; KLEIN, 2010), and is composed of several higher education institutions that are interested in investigating social solutions that provide positive changes in society.

While CRISES does not specifically define the profile of individuals who will be included in the development of social innovations, George, McGahan and Prabhu (2012) emphasize the need for new business models, products and services for disenfranchised individuals, who are members of the Base of the Pyramid (BOP). Thus, innovations may be top-down, developed by public authorities or other organizations, or bottom-up, devised and implemented by individuals or communities. What differentiates social innovations from other types of innovation is the fact that they do not exclusively conform to the logic of the maximization of profit directed to the private sphere (MULGAN et al., 2008; PHILLS JR.; DEIGLMEIER; MILLER, 2008), but instead provide real solutions for social problems or needs.

Even with the establishment of definitions and of the target public, the scope of the concept of social innovation still appears to be broad and can include a large number of initiatives, so that it needs to be treated in more depth (MOULAERT et al., 2005). To do that, we relied on the analytical dimensions of social innovation developed by Tardif and Harrisson (2005), which were based on 49 studies conducted by researchers at CRISES. Using these 
dimensions it is also possible to identify a larger number of theoretical elements that relate to complex phenomena such as the process of innovation for social inclusion (GEORGE; MCGAHAN; PRABHU, 2012).

If social innovations are desirable in developed countries, as is the case in Canada and many other European countries, in developing countries they become essential for growth, including in countries like Brazil. Current data describing the social situation in Brazil show that more than 17 million households have a monthly income up to US\$70.00, while 19 million live on no more than half the monthly minimum wage per capita (IPEA, 2012). On the other hand, Brazil has more than 20,000 collective enterprises that generate new opportunities for disenfranchised individuals (MTE, 2012).

Based on this context, this paper presents two main objectives: (a) evaluate the extent to which the emergence of collective enterprises in the Brazilian handicraft sector is consistent with the dimensions of social innovation postulated in the literature ${ }^{\mathrm{i}}$, and (b) provide insights regarding the questions posed by George, McGahan and Prabhu (2012) which refer to the difference between innovations top-down and bottom-up. Therefore, this paper is structured as follows: the first section presents the main perspectives and understandings regarding social innovation; while the second exhibits the analytical dimensions of social innovations developed mainly by Tardif and Harrison (2005); the third section describes the methodological procedures adopted in this study; the fourth section presents the results obtained from the multiple case study; and lastly, there are the final remarks.

\section{SOCIAL INNOVATION PERSPECTIVES}

The term "social innovation" is increasingly present in debates at the academic, business, government and societal levels. Its development, especially in the social sciences, came only as from the 1990s, due to discontent with the bias of technological approaches towards the economy and innovation policies (MOULAERT et al., 2005). At the same time, positive results were obtained in local development initiatives in Europe and Australia, which made the topic of social innovation amenable to theorization in the contexts of human, local and emancipatory development (HILLIER et al., 2004). Therefore, this field of theory can be considered recent, with the most significant contributions having been made since 2000 .

Despite being relatively new, the theme of social innovation already has several definitions and perspectives that have been developed in accordance with the objectives of and the phenomena studied by each research group and/or researcher. Some of these perspectives are closer to what is considered the traditional understanding of innovation 
(technological), and add the need to change the "social" aspects so that organizations might achieve greater economic growth (DADOY, 1998). In this perspective, social innovation is conducted in order to generate a greater well-being of employees, resulting in greater productivity and hence profitability for organizations (MOULAERT et al., 2005).

Another perspective in the literature is that of Creative Sciences, which is led by Michael D. Mumford. For him, social innovations are associated with the genesis and implementation of new ideas about the different ways in which people organize interpersonal activities in order to address common goals (MUMFORD, 2002; MARCY; MUMFORD; 2007). The process of human creativity would be the great inducer behind the development of social innovations, as shown, for example, in the work done by Benjamin Franklin in the eighteenth century, with the creation of volunteer fire departments, in the United States.

Adopting the perspective of social innovations developed by firms, the Center for Social Innovation (CSI) argues that social solutions must address society as a whole (PHILLS JR.; DEIGLMEIER; MILLER, 2008). As they should be promoted by companies, such innovations are frequently aligned with the principles of Corporate Social Responsibility (CSR). In other words, companies can play an important role in developing innovations that improve the quality of life of populations, such as green technologies, by reducing greenhouse gas emissions in the environment (CONNER, 2010).

Mulgan et al., (2008), on the other hand, define social innovations as new services or activities that are motivated by the goal of reaching a social need and that are predominantly diffused through organizations whose primary purposes are social, in contrast to that postulated by the CSI (private organizations). Much of the literature on social innovation led by Geoff Mulgan comes from the initiatives of the Youth Foundation, which is a British nonprofit organization. Social organizations broadly are, by nature, institutions focused on carrying out activities that meet the needs of specific groups or of societies (MULGAN, 2006).

Social innovations can also be linked to certain territories, such as the Social Innovation, Governance and Community Building (SINGOCOM). This group defines social innovation as the development of innovations for human satisfaction, considering territorial development. Thus, it should be a social solution that provides social inclusion and meets human needs in terms of food, education, culture, health, etc. (MOULAERT et al., 2005). In their concern for the issue of social inclusion, George, McGahan and Prabhu (2012, p.663) define social innovation as "the development and implementation of new ideas that aspire to 
create opportunities that enhance the social and economic wellbeing of disenfranchised members of society."

The term "disenfranchised" refers to people who belong to the BOP, i.e., those which have the smallest economic gains (HART, 2005; PRAHALAD; HART, 2002). This concept was coined to alert large corporations to the opportunities that alternative markets may present, while the needs of those markets could be satisfied. George and colleagues (2012) introduce the concept Base of the Pyramid precisely because, for them, inclusive innovations can be developed by organizations (multinationals, public) or by the actors of a particular community.

In Brazil, however, the term "social innovation" is rarely used compared to that of "social technology". The most widespread concept of social technology is that which comprises re-applicable products, techniques or methodologies, developed in interaction with the community and that provide effective solutions for social transformation (RODRIGUES; BARBIERI, 2008). This definition, disseminated mainly by Renato Peixoto Dagnino of the University of Campinas, is close to the concept of social innovation adopted by the Centre de Recherche sur les Innovations Sociales (CRISES), which highlights the actors involvement in the social innovation process and the social transformation as its mainly goal. Thus, both the definition of social technology and that of social innovation offered by CRISES consist in developing solutions with the participation of actors to achieve social transformation.

Neumeier (2012, p.55), in turn, highlights the changes that would result from a social innovation when defining it as "changes in attitudes, behaviors or perceptions of a group of people joined in a network of aligned interests that in relation to the group's horizon of experience lead to new and improved ways of collaborative action within the group and beyond". Based on the definitions and concepts of social innovation mentioned above, table 1 presents the characteristics of social innovations, who performs them, the results, and their authors/references. 
Table 1 - Characteristics of social innovations, who performs them, the results, authors/references

\begin{tabular}{|c|c|c|c|}
\hline Characteristics & Who performs them & Results & References \\
\hline $\begin{array}{l}\text { Social changes within } \\
\text { organizations }\end{array}$ & Organizations & $\begin{array}{l}\text { Improved welfare, greater } \\
\text { productivity and } \\
\text { profitability }\end{array}$ & Dadoy, 1998 \\
\hline $\begin{array}{l}\text { New ideas for interpersonal } \\
\text { activities }\end{array}$ & Individuals & $\begin{array}{l}\text { Achieve common } \\
\text { objectives }\end{array}$ & $\begin{array}{l}\text { Mumford 2002; } \\
\text { Marcy and } \\
\text { Mumford, } 2007\end{array}$ \\
\hline $\begin{array}{l}\text { Companies promote social } \\
\text { solutions }\end{array}$ & Companies & $\begin{array}{l}\text { Quality of life of } \\
\text { populations }\end{array}$ & $\begin{array}{c}\text { Phills jr., } \\
\text { Deiglmeier and } \\
\text { Miller. } 2008\end{array}$ \\
\hline $\begin{array}{l}\text { Services and activities for } \\
\text { social needs }\end{array}$ & Social organizations & Improved quality of life & $\begin{array}{c}\text { Mulgan et al., 2008; } \\
\text { Mulgan, } 2006\end{array}$ \\
\hline $\begin{array}{l}\text { Development of innovations } \\
\text { for human satisfaction }\end{array}$ & $\begin{array}{c}\text { Governments and or } \\
\text { other actors }\end{array}$ & Territorial development & $\begin{array}{c}\text { Moulaert et al., } \\
2005\end{array}$ \\
\hline $\begin{array}{l}\text { New ideas for creating } \\
\text { opportunities }\end{array}$ & $\begin{array}{l}\text { Companies, } \\
\text { Organizations and } \\
\text { Communities }\end{array}$ & $\begin{array}{l}\text { Social and economic } \\
\text { welfare of disenfranchised } \\
\text { people }\end{array}$ & $\begin{array}{l}\text { George, McGahan } \\
\text { and Prabhu, } 2012\end{array}$ \\
\hline $\begin{array}{l}\text { Process initiated by actors in } \\
\text { response to a human } \\
\text { aspiration and social needs }\end{array}$ & $\begin{array}{l}\text { Actors or organizations } \\
\text { (public, private, social) }\end{array}$ & $\begin{array}{l}\text { Changes in social } \\
\text { relations, to transform a } \\
\text { framework or propose new } \\
\text { cultural guidelines. }\end{array}$ & CRISES, 2012 \\
\hline $\begin{array}{l}\text { Process of collaborative } \\
\text { action among individuals }\end{array}$ & $\begin{array}{c}\text { Collectivity (groups, } \\
\text { networks) }\end{array}$ & $\begin{array}{l}\text { Changes in attitudes, } \\
\text { behavior or perceptions of } \\
\text { a group of people }\end{array}$ & Neumeier, 2012 \\
\hline
\end{tabular}

These concepts revealed some aspects involved in the social innovations development. However, approaches of social innovation often do not address this concept in depth (MOULAERT et al., 2005). To overcome this challenge, we introduce some analytical dimensions developed mainly by Tardif and Harrisson (2005) which address the most important elements in the development of such social solutions.

\section{ANALYTICAL DIMENSIONS OF SOCIAL INNOVATIONS}

The analytical dimensions developed Tardif and Harrison (2005) are based on the key features identified in social innovations. These authors analyzed 49 studies conducted by members of CRISES and found that the essential concepts in the definition of a social innovation intended to bring about social transformation are composed of the following dimensions: a) Transformations; b) Innovative character; c) Characteristics of the Innovation; d) Actors involved; and e) Process of developing the innovation.

The dimension 'Transformations' is first analyzed in terms of the context in which the social innovation is developed. To understand this context, these authors suggest identifying the problematic environment that would spur the creation of innovations. This context is usually marked by crises, whether of an economic or social nature, such as unemployment. In addition, certain changes may lead to the rupture or discontinuity of a given structure within 
the social system which, until then, was in force, such as new modes of governance in labor relations. These changes entail, therefore, structural modifications.

Thus, the problematic context may influence the economic structures at the local, regional and national levels. The change in these structures is the second element of analysis in the dimension 'Transformations'. In other words, crises, discontinuities, ruptures and structural modifications can lead to impacts on a set of economic relationships and bring about more or less radical changes, which lead actors to only make adaptations in this economic sphere (characterized as "adjustments"), develop of new trajectories (called a "conversion"), or create new productive structures, which signals an emergence. The economic structures that are adapted or developed can produce new relationships of labor, production or consumption.

The third analytical elements of this dimension are the impact of the problematic context on the social structures. Tardif and Harrison (2005) suggest that social ties may be restructured and/or reconstructed through the adoption of new practices, whether in terms of the relations of labor, production or consumption, and changes in social relations. These changes can lead to the social exclusion or marginalization of some individuals. Thus, changes to the contexts entail impacts in both economic structures and social structures.

In the dimension 'Innovative Character', Tardif and Harrisson (2005) describe the social action that leads to the formation of an innovation, the type of economy to which it belongs and the different models that can be generated with its implementation and dissemination.

Thus, with the changing context, the actors are driven to act, i.e., to develop solutions to mitigate a particular problem situation. These solutions must be "new", i.e. novel in specific environments where they emerge (TARDIF; HARRISSON, 2005). To develop them, the actors constitute new institutional arrangements, which are the result of their collective action.

The introduction phase of a social innovation entails trials and experiments. Over time, innovative experiences that provide social and/or economic benefits tend to be institutionalized, creating models of development, where the State is the principal actor (BOUCHER, 2001), of labor (new forms of work organization ), of governance (partnership between government and other institutions), of Quebec (belonging to Social Economy). The role of new public policies or programs during the trials and experiments, which may assist or restrict a successful social innovation, is also highlighted. Furthermore, social innovations generate new types of economy, such as the Knowledge Economy, the Mixed Economy and the Social Economy. 
The dimension 'Innovation' is the third dimension in Tardif and Harrison's (2005) model and refers to the type of innovation, its scale and its purposes. For CRISES, social innovations may be a located along a continuum from social to technical. Technical innovations are those that take the form of a product or technology. Social-technical innovations, on the other hand, generally occur within organizations, with the development of some technology. Another type of innovation that occurs within organizations is called "organizational-social innovations", which seek to bring about improvements in the conditions of employees. Yet, the social innovations that can best described as "social" are those developed by actors in civil society, which are not enacted in an organization, a company or as broader solutions developed by the State. The Social Economy of Quebec, Canada, is discussed from this perspective, in terms of generating jobs and new working relationships through a form of cooperative governance (LÉVESQUE; CREVIER, 2002; LÉVESQUE, 2002; BOUCHARD, 2012). The last form of social innovation analyzed here is the institutional form, which mainly refers to solutions in which the State plays the leading role, such as the formulation of new laws. Similarly, George, McGahan and Prabhu (2012) also postulate different types of social innovation, such as products, services or business models.

Whatever the form of a social innovation, Tardif and Harrisson (2005) suggest such innovations need to have local character. The purpose of a particular social innovation must meet the overall objectives of those involved, and seek to reconcile the individual and collective goals. The scope of these general objectives should seek to serve the common good and, for that, there must be cooperation between the actors.

The fourth analytical dimension, 'Actors', describes the various actors involved in the development and implementation of a particular social innovation, of which there can be various types such as: Social, Organizational, Institutional and Intermediary (TARDIF; HARRISSON, 2005). Social actors may be those from within civil society, cooperative movements, unions or community associations. The category of organizational actors includes companies, social economy organizations, collective enterprises and beneficiaries (especially shareholders) of companies. The institutional actors encompass State institutions and the identity, norms and values of each actor. The category of intermediary actors includes socalled "hybrid actors", which refer to the relationship between different actors and result in commissions or bi- or tripartite social networks of alliances or of innovation. 
Rollin and Vincent (2007), in turn, establish a classification of actors that differs from that postulated by Tardif and Harrison (2005). The former highlight the role of the actors in a social innovation, whereas the latter basically classify the actors as social, private, public, or as the partnership between actors. Thus, actors, according to Rollin and Vincent (2007), can be classified into: 1) the holders of the idea, 2) funders, 3) the supporters or partners, and 4) the users. The holders are those actors who create or develop the idea of a social innovation. Funders are responsible for financing the process of social innovation and can be private or public organizations, foundations, etc. Supporters and partners have the role of monitoring, supporting or promoting the social innovation. The users or owners are the actors who actually benefit from the developed social innovation.

The 'Process' dimension of a social innovation, according to Tardif and Harrison (2005), is described in terms of modes of coordination, the means involved and the restrictions to its implementation. The modes of coordination represent the manner in which the players interact and coordinate the development of a social innovation. Thus, one of its characteristics is the mobilization and participation of the actors. As a social innovation involves interaction and cooperation between different actors, Cloutier (2003) affirms that the identities, values and norms of each actor become "blended", resulting in a collective learning. In other words, the actors learn new knowledge and new skills with the exchange of information and training. This collective learning can lead to, then, the generation of new rules and new social patterns. The mode of coordination also involves the assessment of the social innovation during its development, which mainly aims to identify aspects that can be improved so that innovation to achieve the goal for which it was created.

Negative aspects or those that are not in accordance with the process of a social innovation are referred to as restrictions by Tardif and Harrison (2005), and unfavorable factors by Perreault and Rollin (2008). These restrictions include, for example, the complexity and uncertainty of the social dynamics, the resistance of the actors and the tensions they present due to the novelty, and the requirements needed in order to establish a commitment. Moreover, the institutional inflexibility of the environment may even prevent the spread of a constituted social innovation. Yet another analytical element within this dimension refers to the means by which the process of this innovation is established. A major goal of social innovation projects is that all the strategic actors are involved in the innovation process, which, thus, requires cooperation between the parties. Besides cooperation, CRISES points out the need for negotiation, integration, dialogue and formal and informal agreements 
(partnership) to facilitate the development of good relationships between the actors. The elements highlighted in each analytical dimension of a social innovation are shown in table 2 .

Table 2 - The analytical dimensions of social innovation according to the CRISES

\begin{tabular}{|c|c|c|c|}
\hline \multirow{6}{*}{ TRANSFORMATION } & Micro-context & Economic & Social \\
\hline & Crisis & Emergence & Re-composition \\
\hline & Rupture & Adaptation & Reconstruction \\
\hline & Discontinuity & Labor relations & Exclusion/ \\
\hline & & Relations of & Practice/Change \\
\hline & Structural modifications & $\begin{array}{l}\text { production and } \\
\text { consumption }\end{array}$ & Social relations \\
\hline \multirow{5}{*}{$\begin{array}{l}\text { INNOVATIVE } \\
\text { CHARACTER }\end{array}$} & Model & Economy & Social action \\
\hline & Work & Knowledge & Trials \\
\hline & Development & & Experiments \\
\hline & Governance & Mixed & Policies/Programs \\
\hline & Quebec & Social & $\begin{array}{l}\text { Institutional } \\
\text { arrangements } \\
\text { Social Regulation }\end{array}$ \\
\hline \multirow{5}{*}{ INNOVATION } & & Types & Purpose \\
\hline & & Technical & Common good \\
\hline & Scale & Social-technical & General interest \\
\hline & Local & Social & Collective interest \\
\hline & & $\begin{array}{l}\text { Organizational } \\
\text { Institutional }\end{array}$ & Cooperation \\
\hline \multirow{5}{*}{ ACTORS } & Social & Organizations & Institutions \\
\hline & Movements & Companies & State \\
\hline & Cooperatives/Communities & Organizations & Identity/Values/Norms \\
\hline & Civil society & Social Economy & $\begin{array}{l}\text { Intermediaries } \\
\text { Committees }\end{array}$ \\
\hline & Unions & $\begin{array}{l}\text { Collective } \\
\text { organizations }\end{array}$ & $\begin{array}{l}\text { Social networks/ of } \\
\text { alliance/ of innovation }\end{array}$ \\
\hline \multirow{7}{*}{ PROCESS } & Mode of & & \\
\hline & & Means & Restrictions \\
\hline & $\begin{array}{l}\text { Coordination } \\
\text { Assessment }\end{array}$ & Partnerships & Complexity \\
\hline & Participation & Integration & Uncertainty \\
\hline & Mobilization & Negotiation & Resistance/Tension \\
\hline & & Empowerment & Commitment \\
\hline & Learning & Diffusion & $\begin{array}{l}\text { Institutional } \\
\text { Inflexibility }\end{array}$ \\
\hline
\end{tabular}

Source: Based on Tardif and Harrison (2005).

After the presentation of the analytical dimensions of social innovation, the following topic considers the methodological procedures of this study.

\section{METHODOLOGICAL PROCEDURES}

To achieve the proposed objective, a multiple case study (Yin 2005) was conducted in an effort to permit a literature replication and a comparative analysis between the cases. The handicraft sector was chosen because it has recently experienced growth, as shown by the significant increase in the number of invoices issued. It is also an important sector in Brazil because it employs a large proportion of women, the less educated and people over 40 years of age. In addition, the State of Rio Grande do Sul (RS) has the largest number of solidarity 
enterprises in Brazil, demonstrating its strong involvement with the Solidarity Economy, which is equivalent to the Canadian Social Economy. The handicraft sector involves approximately $70 \%$ of the enterprises in urban areas within the State.

To choose the organizations that would be the objects of this study, exploratory interviews were conducted with three experts involved with Solidarity Economy organizations in the handicrafts sector of RS: Handicraft Program Coordinator of the Riograndense Association of Rural Technical Assistance and Extension Enterprises (EMATER/ASCAR, 2012) at the state level; the Handicraft Program Coordinator of the Micro and Small Enterprises Support Service (SEBRAE, 2012); the Coordinator of Esperança Project/Cooesperança of Solidarity Economy. The main criterion for selection of cases was the social transformation generated by the enterprises, since the social innovations analyzed by CRISES were directed mainly to this kind of transformation.

The six handicraft Solidarity Economy enterprises recommended were: 1) Cooperativa Lã Pura (Pure Wool Cooperative), 2) Cooperativa dos Artesãos do RS (COOPARIGS) (Cooperative of Artisans of RS); 3) Grupo Novo Horizonte (New Horizon Group); 4) Grupo Misturando Arte (Blending Art Group); 5) Associação dos Artesãos de Vila Flores (AAVIF) (Vila Flores Artisans Association); and 6) Associação Tecelagem Lavrense (Lavrense Weaving Association). Data were collected from these enterprises through 22 semi-structured interviews (GIL, 2008) held in October and November 2010. Each interview was fully transcribed and lasted 46 minutes on average. Some characteristics of the researched enterprises are shown in table 3, such as its name, year of founded, number of artisan participant, raw materials used and information about the interviewed people. This study also used secondary data sources (websites and documents). 
Table 3 - Enterprise, year of foundation, number of artisans, raw materials used and interviewee

\begin{tabular}{|c|c|c|c|c|}
\hline Enterprises & $\begin{array}{l}\text { Year } \\
\text { founded }\end{array}$ & $\begin{array}{l}N^{\circ} \text { of } \\
\text { Artisans }\end{array}$ & $\begin{array}{c}\text { Raw materials } \\
\text { used }\end{array}$ & Interviewee: position and institution \\
\hline \multirow{4}{*}{$\begin{array}{c}\text { Cooperativa Lã } \\
\text { Pura }\end{array}$} & \multirow{4}{*}{2005} & \multirow{4}{*}{39} & \multirow{4}{*}{$\begin{array}{l}\text { Sheep wool and } \\
\text { fabrics. }\end{array}$} & President of the Cooperative \\
\hline & & & & Treasurer of the Cooperative \\
\hline & & & & EMATER Extension worker \\
\hline & & & & The former project manager from SEBRAE \\
\hline \multirow{3}{*}{ COOPARIGS } & \multirow{3}{*}{1980} & \multirow{3}{*}{90} & \multirow{3}{*}{$\begin{array}{l}\text { Straw from wheat } \\
\text { and corn. sheep } \\
\text { wool, cow leather. } \\
\text { wicker and glass. }\end{array}$} & President of the Cooperative \\
\hline & & & & Ex-President of the Cooperative \\
\hline & & & & $\begin{array}{l}\text { Former-coordinator of Handicraft Project at } \\
\text { SEBRAE }\end{array}$ \\
\hline \multirow{4}{*}{$\begin{array}{l}\text { Grupo Novo } \\
\text { Horizonte }\end{array}$} & \multirow{4}{*}{1999} & \multirow{4}{*}{08} & \multirow{4}{*}{$\begin{array}{l}\text { Threads, ribbons, } \\
\text { buttons and stones. }\end{array}$} & Member 01 \\
\hline & & & & Member 02 \\
\hline & & & & Member 03 \\
\hline & & & & Coordinator of the Projeto Esperança \\
\hline \multirow{4}{*}{$\begin{array}{c}\text { Grupo } \\
\text { Misturando } \\
\text { Arte }\end{array}$} & \multirow{4}{*}{2005} & \multirow{4}{*}{10} & \multirow{4}{*}{$\begin{array}{l}\text { T-shirts, banners. } \\
\text { used plastic bags } \\
\text { and medical waste, }\end{array}$} & Member 01 \\
\hline & & & & Member 02 \\
\hline & & & & Assistant of Social Projects at AVESOL \\
\hline & & & & $\begin{array}{l}\text { Representative of the Förum Gaicho de } \\
\text { Econ. Solidaria }\end{array}$ \\
\hline \multirow{3}{*}{$\begin{array}{l}\text { Associação } \\
\text { dos Artesãos de } \\
\text { Iila Flores }\end{array}$} & \multirow{3}{*}{2002} & \multirow{3}{*}{45} & \multirow{3}{*}{$\begin{array}{l}\text { Straw from wheat } \\
\text { and corn, fabric } \\
\text { and thread. }\end{array}$} & President of the Association \\
\hline & & & & EMATER Extension worker \\
\hline & & & & Director of the Department of Tourism \\
\hline \multirow{3}{*}{$\begin{array}{c}\text { Associação } \\
\text { Tecelagem } \\
\text { Lavrense }\end{array}$} & \multirow{3}{*}{1992} & \multirow{3}{*}{32} & \multirow{3}{*}{ Sheep wool. } & President of the Association \\
\hline & & & & EMATER Extension worker \\
\hline & & & & EMATER Regional Assist \\
\hline
\end{tabular}

Data analysis was carried out in the light of the theoretical approaches included in the literature review of this paper. The guiding analytical categories were the dimensions of social innovation proposed by Tardif and Harrison (2005): 'transformations', 'innovative character', 'innovation', 'actors' and 'process'. Each dimension was analyzed according to the elements composing it, while, in the 'actors' dimension the classification proposed by Rollin and Vincent (2007) was added. Finally, a comparative analysis was carried among the studied cases.

\section{RESULTS ANALYSIS}

The results will be presented according to the dimensions of social innovation highlighted by Tardif and Harrison (2005). In each of these dimensions the most relevant aspects identified in the formation of researched collective enterprises will be highlighted.

\subsection{TRANSFORMATIONS DIMENSION}

The 'Transformations' dimension is analyzed in terms of the context, economic structures and social structures (TARDIF; HARRISSON, 2005). Only two the cooperatives 
had these three elements of analysis, and one reason for this finding is that the individuals involved in the founding of the other projects had not developed prior solutions to problematic situations they faced. In the town of San Borja - the context of the cooperative La Pura, there was a discontinuity in the purchase of handicrafts made from sheep wool, which led to an adaptation in the manner of selling the handicrafts, through street markets. This led to the adoption of new practices by the town's artisans, and the establishment of new social relations with other artisans of the town. In the case of COOPARIGS - context of the Ilha Grande dos Marinheiros, in Porto Alegre, there was discontinuity in the sheep farming, which impacted on the amount of raw material available. This difficulty motivated the search for adaptations (jobs in major centers) through new working practices, which led to changes in the social relations of the island's inhabitants.

The contexts of both the two cooperatives mentioned (La Pura and COOPARIGS) and those of the other four cases examined continue to face difficult situations. The main problem faced by the members of the La Pura cooperative are concerned with the difficulty of marketing the items made of wool. Other enterprises were also in response to the difficulty of marketing handicrafts: Grupo Novo Horizonte, Grupo Misturando Arte and Associação Tecelagem Lavrense. Moreover the context of COOPARIGS related to an unfavorable situation where many women did not have any craft, further exacerbating the socioeconomic situation of the inhabitants. The context of the foundation of the AAVIF enterprise was also differentiated due to concern of local authorities with the continuance of a project intended to preserve the craft techniques based in the municipality of Vila Flores that was already underway.

Thus, the problematic contexts are the difficulty in marketing handicrafts, the preservation of craft techniques and concern with women who had not learned any craft. That is, only the enterprise formed in order to preserve the local culture was not directly involved with the issue of generating income. Some enterprises also highlighted an unfavorable social situation, such as symptoms of depression and low self-esteem on the part of the artisans involved. All the analyzed cases showed a specific problem and an unsatisfied demand, which are suitable environments for innovative solutions, as was highlighted by Cloutier (2003).

\subsection{INNOVATIVE CHARACTER}

The 'Innovative Character' dimension includes the development of an innovative solution that would overcome the problems identified in the 'transformations' dimension. In all the analyzed cases, the development of innovative solutions concerned the formation of 
solidarity enterprises that produce and sell handicrafts. These developments linked to the Solidarity Economy would seek to address social and economic needs, with their social and economic value reverting to the collectivity of individuals involved. In the cases of Lã Pura, AAVIF and Tecelagem Lavrense, as proposed by Tardif and Harrison (2005), institutional arrangements were made for the implementation of innovative solutions. La Pura, for instance, came about as a result of an arrangement involving the Ministry of Agrarian Development, SEBRAE and EMATER in the town. All the agreements envisaged cooperation in order to improve the development of the activities at the collective enterprises. By contrast, in the other analyzed cases - COOPARIGS, Novo Horizonte; and Misturando Arte - there were no institutional arrangements involved at the beginning of its activities.

The proposed solutions passed through at least one stage of trial and experiment, as described by Tardif and Harrison (2005). The "trials" refer to the meetings held to establish the enterprises. The meetings included discussions regarding the roles with the collective and craft classes were given (at COOPARIGS), the development of craft collections (at La Pura) and the improvement of existing handicrafts (at Tecelagem Lavrense). The experiment phase in the analyzed cases refers to the beginning of collective activities. However, the length of the trial and experiment phase varied in each case. This stage lasted several years in some enterprises, namely COOPARIGS and Tecelagem Lavrense, while others were able to develop more quickly. Moreover, public policies played an important role in the creation and development of Lã Pura, AAVIF of Tecelagem Lavrense because the projects were induced by actors from the public sphere, i.e., public policy influenced the foundation of enterprises. The other studied enterprises also benefited from public policy or incentives during their development process.

In a given context, a solution becomes institutionalized, when comes to be seen as an example or model to be followed by other organizations or institutions. In the analyzed cases here, this step basically occurred at the end of the trial and experiment phase and during the start of the model phase. The institutionalization of the enterprises mainly occurred in relation to craft groups with whom they interacted. The La Pura cooperative, for example, came to be recognized as being legitimate or institutionalized by the other handicraft cooperatives that are part of the project Talentos do Brasil (Brazil's Talents) at the Ministry of Agrarian Development, since this project gave rise to the cooperative.

The handicraft enterprises became emerging development models, in terms of Tardif and Harrison (2005). These models originally refer to the Social Economy initiatives in the 
province of Quebec, Canada. However, all the cases analyzed in Rio Grande do Sul also showed the spread of the organizational model, that is, of the self-management form of acting collectively. Besides the spread of this form of working, some groups also stood out for their innovative products or production processes. As with duration of the trial and experiment phase, the length of the model phase also varied amongst the analyzed enterprises, precisely because this phase is a consequence of the first.

\subsection{INNOVATION DIMENSION}

In the 'Innovation' dimension amongst the cases that were investigated here showed similarity in its analytical elements. These elements are the type of innovation undertaken, its scale and its purpose. In all cases, the solution developed was a social innovation, that is, the innovation brought together social actors (as well as other agents) in order to develop a solution that would meet the needs of those involved. These innovations did not correspond to the logic of market competition, and also differ from the types of innovation highlighted by CRISES (technical, social-technical, organizational and institutional), since they were not developed within an organization and did not encompass a broader context, as in institutional social innovations.

Tardif and Harrison (2005) argue that social innovations examined by CRISES refer to solutions that are specific to a place or territory. The scale of analyzed social innovations also showed their local character being located in a particular county or district in RS. However, only COOPARIGS, which was initially formed by residents of the Ilha Grande dos Marinheiros (a district of the State capital, Porto Alegre) expanded its operations into the State, mostly as from 1989, which did not occur with other enterprises investigated.

The purpose of the social innovations was, in most cases, the generation (or complement) of employment and income. With this in mind, the collective enterprises formed sought to address the needs of the actors involved and the common good. When conducting their study, Tardif and Harrison (2005) analyzed various social innovations, some of which involved the development of solutions that required negotiation, such as between trade unions, companies and the State. Accordingly, these authors point out the importance of having consensus and a common agreement. In the cases analyzed, the actors involved with the artisans and residents sought to contribute to the formation of the enterprises, and no divergent interests were expressed, which highlighted the willingness of the actors to cooperate to fulfill their needs. 


\subsection{ACTORS DIMENSION}

In the 'Actors' dimension, 'the participants involved the process of creating and implementing a social innovation were analyzed (TARDIF; HARRISSON, 2005). The analysis of the cases showed that various types of actors were involved in the formation of the analyzed enterprises. As the solutions developed were intended to meet the needs of residents in a given location, actors from civil society, in terms of Tardif and Harrison (2005), were present in all the cases. These actors were also the users of the studied social innovations.

The studied cases presented different actors that may be called "holders of the idea", according to the classification of Rollin and Vincent (2007). The analyzed crafts groups Novo Horizonte and Misturando Arte - were conceived of by the actors from civil society, who are the holders of the idea to innovate as well as the users of the innovation. In the cases of La Pura and AAVIF the efforts were promoted by hybrid actors, in terms of Tardif and Harrison (2005). The hybrid actor in the foundation of the La Pura enterprise was composed of three representatives of the State: Ministry of Agrarian Development, EMATER and SEBRAE. In the case of $A A V I F$, the hybrid actor consisted of the Atuaserra association together with the Department of Tourism of the municipality of Vila Flores. The COOPARIGS was conceived of by the leader of SADI, which is a community movement, while Tecelagem Lavrense was established by the local office of EMATER in the municipality of Lavras do Sul. Thus, it can be seen that, of the six cases studied, four were induced by entities or organizations.

The actors that support the social innovations, who constitute another category for Rollin and Vincent (2007), were also identified in all the cases. A variety of support actors was found in the course of the activities of the analyzed enterprises: actors representing the State, companies, NGOs and social movements. The support actors in the induced enterprises - Lã Pura, COOPARIGS, AAVIF and Tecelagem Lavrense - were basically State representatives. Support is given primarily in terms of skills and staff training to ensure that projects can achieve independence, and thus achieve the goals of generating employment and income. The non-induced enterprises, the groups Novo Horizonte and Misturando Arte, were mainly supported by Solidarity Economy movement and by the enterprises that make up this movement. This support takes the form of exchanging knowledge and information between enterprises and legitimacy offered by such movements and networks.

Rollin and Vincent (2007) also point out that the process of developing a social innovation often includes funding actors. In the studied cases, many of the actors representing 
the State, acted, both as supporters and as funders. Only Lã Pura and Tecelagem Lavrense presented actors can that can be classified exclusively as funders (companies). The funding actors assist the enterprises with economic resources for participation in fairs or courses.

\subsection{PROCESS DIMENSION}

The process of forming social innovations is analyzed through the elements "mode of coordination", "means" and "restrictions" (TARDIF; HARRISSON, 2005). The mode of coordination refers to the involvement of the actors in the process of developing a social innovation. In the cases analyzed, the mobilization of actors was apparent at the beginning of the process of forming the enterprises, which was done by the actors holding the idea of each social innovation. The participation of the actors was also apparent in all the cases studied and depended mainly on the roles played by the actors in this process. In the cases of the enterprises established by organizations or entities (Lã Pura, COOPARIGS, AAVIF and Tecelagem Lavrense) not only the artisans or the residents of a particular place participated, but also the inducer actors, such as SEBRAE and EMATER, in the case of La Pura. In the groups Misturando Arte and Novo Horizonte, it was mainly the artisans directly involved in the enterprise who participated. The participation of the actors is a constant in the formation of the studied social innovations, since they are self-managed enterprises.

Social innovations, as they require the participation of actors, usually result in a learning process (CLOUTIER, 2003). In the analyzed cases, learning was highlighted during all the developmental phases of the enterprises. This involved learning both in terms of acting collectively and in relation to issues regarding the products, for example, improving techniques. Moreover, the learning generated by the exchange of experiences among enterprises participating in the Solidarity Economy movement (Novo Horizonte and Misturando Arte), which established interorganizational relationships with a view to exchanging experiences, should be highlighted.

Restrictions to the process of developing social innovations were observed in the six analyzed enterprises. In all the cases, the various problems encountered by the enterprises led to uncertainty and tension among the artisans. In the case of La Pura, these restrictions were related to management problems with a vendor, the limited working capital for the purchase of raw materials or equipment and the dependence of the enterprise in relation to its partners. The COOPARIGS faced the difficulty of marketing its woolen products. The Novo Horizonte group also experienced uncertainty related to insufficient sales. The group Misturando Arte, in turn, experienced tension and uncertainty because many artisans affiliated to the group 
abandoned it and some uncertainty due to its focus on the militancy of the Solidarity Economy movement, while there was no great concern regarding the sustainability of enterprise. In the $A A V I F$, there was a dependence on its partners that contributed to the uncertainty in the continuity of the association. The latter case - Tecelagem Lavrense - also showed a similar dependency, and recent internal conflicts have generated tension in the group.

It is also noteworthy that three of the studied projects had difficulties with respect to the low level of commitment made by artisans, which is one of the constraints pointed out by Tardif and Harrison (2005). In Lã Pura, the artisans, especially in rural areas, participated little in the decision-making processes. In COOPARIGS, because its members lived in different municipalities in the State, there were difficulties bringing the artisans together and stimulating interest in the management of the enterprise. In $A A V I F$, the limited participation is due, according to the interviewees, to different types of public included in the enterprise. Thus, even when the innovative solutions involve the participation of user actors, some enterprises had difficulties in retaining such participants. Among the studied enterprises, those groups participating in the Solidarity Economy, namely Novo Horizonte and Misturando Arte, were notable exceptions with regard to the participation of their members.

"Complexity" was identified as a restriction in the cases of Lã Pura, COOPARIGS, $A A V I F$ and Tecelagem Lavrense. This restriction refers primarily to the difficulties encountered in acting in the collective, which were related to the commitment of the members and the entrepreneurial spirit of artisans. Another restriction identified in the enterprises concerned the resistance of some of the artisans belonging to enterprises, such as the lack of commitment on the part of the artisans to deliver the products within agreed within the time agreed with customers or the possibility of losing retirement benefits. Only the Tecelagem Lavrense association highlighted institutional inflexibility as a difficulty, because of the need for more public policies capable of stimulating their handicraft project.

In the 'Process' dimension, the means in which the process of developing social innovations occurs are also analyzed (TARDIF; HARRISSON, 2005). In all the cases studied, the means that stood out were the integration, partnership and diffusion of the social innovations. During the trial and experiment stage, the enterprises integrated the actors involved, as well as the partnership with organizations or institutions. During the emerging development model stage, the means that stood out were those of partnership and the diffusion of the social innovations. Empowerment was highlighted in cases of COOPARIGS 
and Tecelagem Lavrense when some artisans were trained and managed to open their own businesses. Moreover, COOPARIGS undertook negotiations with SEBRAE as a result of the brand Mão Gaúcha was created in order to commercialize the cooperative's products. Also of particular note is that the groups Novo Horizonte and Misturando Arte, while still in the emerging development stage, began to integrate with other enterprises, especially those linked to the Solidarity Economy movement. Figure 1 provides a synthesis of the main elements that were highlighted in the formation of economic solidarity enterprises according to a process of social innovation.

Transformations

Discontinuities Adaptions

New practices adoption

New social relations

Problematic contexts

Users of social innovation:

civil society actors

Holders of the idea: civil

society, hybrid and

community movement

Supporters: State

representatives, companies,

NGOs and movements

Funders: State

representatives, companies
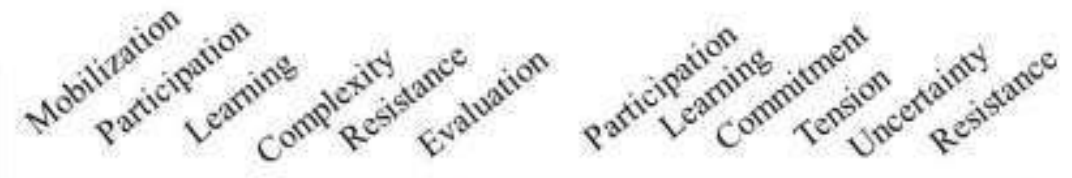

Trial/ Experiment Phase Emergent Development Model

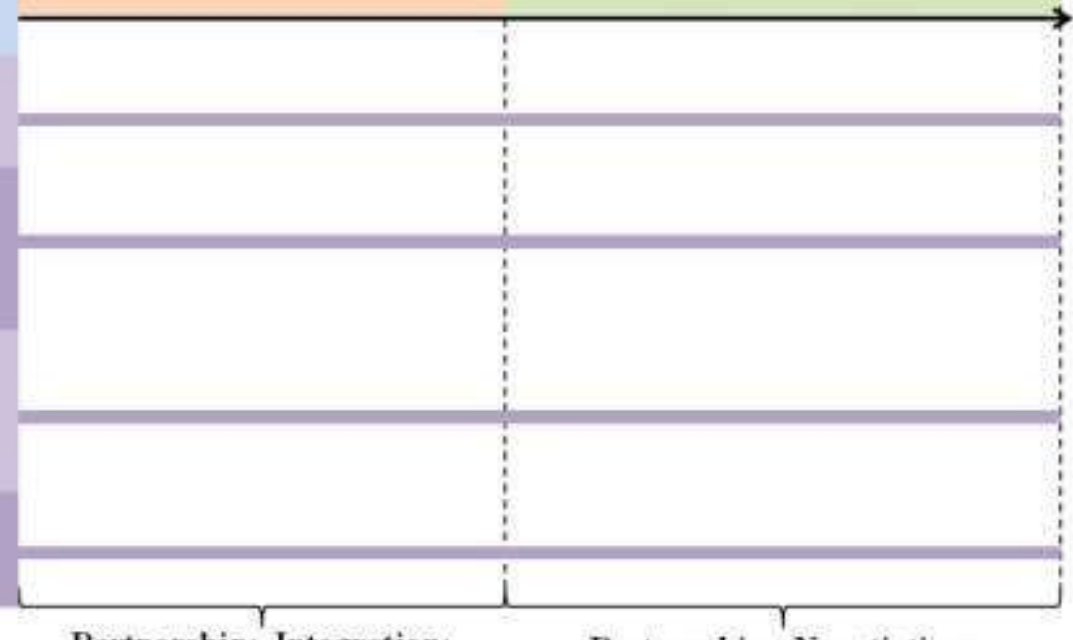

Partnership; Integration; Empowerment

Partnership; Negotiation;

Diffusion; Empowerment

Figure 1 - The process of collective enterprises formation according to the main aspects of the social innovations dimensions

\section{FINAL REMARKS}

The main objective of this paper was to assess to what extent the emergence of collective enterprises in the Brazilian handicraft sector is consistent with the dimensions of social innovation postulated in the literature. To accomplish this purpose, a multiple case study was conducted. It was found that most of the elements of the dimensions of social innovation proposed mainly by Tardif and Harrison (2005) and Rollin and Vincent (2007) were identified in the cases studied. In general, the projects analyzed were created and 
developed according to different processes involving various actors, who played different roles throughout these processes.

The studied enterprises were developed within problematic contexts, went through trial and experiment phases, which were institutionalized, and the enterprises have become emerging development models. These enterprises also contemplated the need of the community and the common good. Several actors were identified in the formation of these enterprises, all of which relied on the actors referred to as holders of the idea, funders, supporters and users. The mobilization and participation of the actors were also representative as was the learning generated by the process of developing the analyzed social innovations. This process involved restrictions that generated uncertainty and tension among the artisans. Yet, the process was achieved through integration and partnership among the actors, and solutions developed spread to other contexts.

Thus, the analytical dimensions of social innovations proposed by Tardif and Harrison (2005) and the classification of the actors developed by Rollin and Vincent (2007) can be considered adequate for understanding the formation of collective enterprises in the handicraft sector, since they permit the identification of the main elements within the solutions developed with a considerable number of actors, which had previously been noted by Bouchard (2012). The studied social innovations sought primarily to meet the income generation, employment and, in some cases, the social needs of the individuals involved. This study then has facilitated a greater understanding of how social solutions are collectively constructed, which can be used to generate other social innovations or improve existing ones. Furthermore, it should be pointed out that the enterprises induced through public policies had low levels of participation and high levels of dependence on their partners, thereby demonstrating important differences when compared to spontaneously formed enterprises doubts previously expressed by George, McGahan and Prabhu (2012). Therefore, it would be particularly important for the coordinators of these enterprises to develop measures to overcome this difficulty.

This study focused on the key dimensions of social innovation presented in the literature. However, this was not an attempt to analyze in detail the results generated by the social innovations. Thus, future studies can contribute significantly by adding this dimension in their analysis. Another suggestion for further research would be to look deeper into the learning processes among the actors involved in the process of developing social innovations, as well as the governance characteristics needed to better manage this process. Finally, it 
would relevant to conduct studies involving all the members of a particular collective enterprise so that the analyzed elements might be better addressed.

\section{REFERENCES}

ANDREW, C.; KLEIN, J. L. Social innovation: what is it and why is it important to understand it better. In: CRISES. Centre de Recherche Sur Les Innovations Sociales Cahiers du CRISES. Québec, 2010.

BOUCHARD, M. J. Social Innovation, an analytical grid for understanding the social economy: the example of the Québec housing, Services Business, v.6, p. 47-59, 2012.

BOUCHER, J. L. Transformations sociales et orientation de la société. In: BOUCHER, J. L.; FOTEV, G.; KOLEVA, S. (Orgs.). Mutations de société et quête de sens: une rencontre entre des sociologues bulgares et québécois. Sofia: Éditions LIK, 2001. p. 19-44.

CLOUTIER, J. Qu'est-ce que l'innovation sociale? In: CRISES. Centre de Recherche Sur Les Innovations Sociales Cahiers du CRISES. Québec, 2003.

CONNER, A. Ideas research. Stanford Social Innovation Review, spring, p. 6-11, 2010.

CRISES. Centre de Recherche sur les Innovations Sociales. Rapport Annuel des activités scientifiques du CRISES 2009-2010. Quebec, 2010.

DADOY, M. L'innovation sociale, mythes et realités: l'innovation en question. Éducation Permanente, v. 134, p. 41-53, 1998.

EMATER/ASCAR. Associação Rio-Grandense de Empreendimentos de Assistência Técnica e Extensão Rural. 2012. Disponível em: <http://www.emater.tche.br/site/>. Acesso em: 12 dez. 2012.

GEORGE, G.; MACGAHAN, A. M.; PRABHU, J. Innovation for Inclusive Growth: Towards a Theoretical Framework and Research Agenda. Journal of Management Studies, v. 49, n. 4, p. 661-683, 2012.

GIL, A. C. Métodos e técnicas de pesquisa social. 6. ed. São Paulo: Atlas, 2008.

HART, S. L. Innovation, Creative Destruction and Sustainability. Research Technology Management, v. 48, n. 5, p. 21-28, 2005.

HILLIER, J.; MOULAERT, F.; NUSSBAUMER, J. Trois essais sur le rôle de l'innovation sociale dans le développement spacial. Géographie, Economie, Société, 6, 129-152, 2004.

HOPWOOD, B.; MELLOR, M.; O'BRIEN, G. Sustainable development: mapping different approaches. Sustainable Development, n. 13, p. 38-52, 2005.

IPEA (2012). Políticas Sociais de Assistência Social. Disponível em:

<http://www.ipea.gov.br/portal/images/stories/PDFs/politicas_sociais/bps_20_cap02.pdf >. Acesso em 10 out 2012. 
LÉVESQUE, B. Les entreprises d'economie sociale, plus porteuses d'innovations sociales que les autres? In: CRISES. Centre de Recherche Sur Les Innovations Sociales Cahiers du CRISES. Québec, 2002.

LÉVESQUE, B.; CREVIER, F. Les impacts des parcs scientifiques à travers la contribution des innovations sociales et des sciences et humaines. In: CRISES. Centre de Recherche Sur Les Innovations Sociales Cahiers du CRISES. Québec, 2002.

MARCY, R. T.; MUMFORD, M. D. Social innovations: enhancing creative performance through causal analysis. Creativity Research Journal, v. 19, p. 123-140, 2007.

MOULAERT, F. et al. Towards alternative model(s) of local innovation. Urban Studies, v. 42, n. 11, p. 1969-1990, 2005.

MTE (2012). O que é a Economia Solidária. Disponível em:

<http://www.mte.gov.br/ecosolidaria/ecosolidaria_oque.asp> . Acesso em: 14 mar. 2012.

MULGAN, G. et al. Social innovation: what it is, why it matters, how it can be accelerated. Oxford: Skoll Centre for Social Innovation, 2008.

MULGAN, G. The process of social innovation. Innovations, spring, p. 145-162, 2006.

MUMFORD, M. D. Social Innovation: ten cases from Benjamin Franklin. Creativity Research Journal, v. 14, n. 2, p. 253-266, 2002.

NEUMEIER, S. Why do social innovations in rural development matter and should they be considered more seriously in rural development research? - Proposal for a stronger focus on social innovations in rural development research. Sociologia Ruralis, v. 52, n. 1, p. 48-69, 2012.

PERREAULT, N.; ROLLIN, J. Acteurs et processus d'innovation sociale au Québec: une etude du Réseau québécois en innovation sociale. Développement Social, v. 9, n. 1, p. 59-60, 2008.

PHILLS JR., J. A.; DEIGLMEIER, K.; MILLER, D. T. Rediscovering social innovation. Stanford Social Innovation Review, Fall, p. 34-43, 2008.

PRAHALAD, C. K.; HART, S. L. The fortune at the bottom of the pyramid.

Strategy+Business, v. 26, p. 54-67, 2002.

ROBINSON, J. Squaring the circle? Some thoughts on the idea of sustainable development. Ecological Economics, v. 48, p. 369-384, 2004.

RODRIGUES, I.; BARBIERI, J. C. A emergência da tecnologia social: revisitando o movimento da tecnologia apropriada como estratégia de desenvolvimento sustentável.

Revista de Administração Pública, v. 42, n. 6, p. 1069-1094, 2008.

ROLLIN, J.; VICENT, V. Acteurs et processus d'innovation sociale au Québec. Québec: Université du Québec, 2007.

SEBRAE. Serviço de Apoio às Micro e Pequenas Empresas. 2012. Disponível em: <http://www.sebrae.com.br/>. Acesso em: 02 dez. 2012. 
TARDIF, C.; HARRISSON, D. Complémentarité, convergence et transversalité: la conceptualisation de l'innovation sociale au CRISES. In: CRISES. Centre de Recherche Sur Les Innovations Sociales Cahiers du CRISES. Québec, 2005.

YIN, R. K. Estudo de caso: planejamento e métodos. 3. ed. Porto Alegre: Bookman, 2005.

\footnotetext{
${ }^{\mathrm{i}}$ This paper is derived from a dissertation that was defended in 2011 and received the award of Science and Sustainability (Socio-environmental technologies to reduce poverty) from Capes and Vale S.A. (2013) and also the award for Best Dissertation in Management from the Brazilian Society of Rural Economics, Management and Sociology (2012).
} 